\title{
A Negative Feedback Regulation of Replanted Soil Microorganisms on Plant Growth and Soil Properties of Peach
}

\author{
Li-Hui LÜ ${ }^{1}$, A. K. SRIVASTAVA ${ }^{2}$, Yun-Lou SHEN ${ }^{1}$, Qiang-Sheng WU1,3* \\ ${ }^{1}$ Yangtze University, College of Horticulture and Gardening, Jingzhou, Hubei 434025, \\ China;lvlh92@163.com;1923497291@qq.com;wuqiangsh@163.com (*correspondingauthor) \\ ${ }^{2}$ ICAR-Central Citrus Research Institute, Nagpur 440033, Maharashtra, India; aksrivas2007@gmail.com \\ ${ }^{3}$ University of Hradec Kralove, Faculty of Science, Department of Chemistry, Hradec Kralove 50003, Czech Republic; wuqiangsh@163.com
}

\begin{abstract}
Replant disease is one of the main growth limiting factors, interfering with plant growth and yield of stone fruit trees such as peach trees. The ecological feedback mechanisms by replanted soil microbes regulating peach growth and soil structure are rarely known. In our study, rhizosphere soils collected from 18 -year-old peach trees were used to plant new peach seedlings, and all soil microbes $(R)$ and soil microbes with the size of $<100 \mu \mathrm{m}\left(\mathrm{R}_{<100}\right)$ and $<40 \mu \mathrm{m}\left(\mathrm{R}_{<40}\right)$ were applied into peach rhizosphere. After 90 days of microbial inoculation, compared with no microbe treatment $\left(R_{0}\right)$, the treatments such as $R_{2}, R_{<40}$, and $\mathrm{R}_{<100}$ reduced plant growth performance (biomass, leaf number, plant height, and stem diameter) and root morphology (total length, projected area, surface area, diameter, and volume), with treatment $\mathrm{R}$ being the most inhibition of all other treatments. Similar response of treatment $\mathrm{R}$ was observed on changes in concentrations of chlorophyll $a$, chlorophyll $b$, and carotenoid. Interestingly, compared with $\mathrm{R}_{0}$ treatment, $\mathrm{R}_{<100}$ treatment produced a significant increase in glomalin-related soil protein (GRSP), percentage of water-stable aggregates in size of $0.25-0.5 \mathrm{~mm}$, soil polyphenol oxidase activities and soil catalase activities. However, $\mathrm{R}$ treatment dramatically decreased the percentage of water-stable aggregates in size of $2-4 \mathrm{~mm}$ and soil peroxidase activities. Our results suggested that replanted soil microbes, especially with the size of $<100 \mu \mathrm{m}$, played a strong negative role on plant growth and rhizosphere biology of peach.
\end{abstract}

Keywords: biomass; chlorophyll; GRSP; soil enzymes; soil microbes

\section{Introduction}

Peach (Prunus persica L. Batsch) is globally a kind of deciduous fruit trees, which has a long history of cultivation. However, peach cultivation often faces a common problem, popularly known as soil replant disease, which results in a variety of symptoms like reduced growth, severe gummosis, leaf chlorosis, root browning, reduced yield, and even tree death (Bent et al., 2009; Tewoldemedhin et al., 2011). Changes soil microbiome are considered most important driving factor to such problem due to gradual shift from high-fertility bacterial to low-fertility fungal types (Sun $e t$ al., 2015). According to Benzri et al. (2005), soil bacteria such as Bacillus, decomposed cyanogenic glycosides under peach roots to produce some toxic substances (i.e., benzoic acid, cyanohydrogen acid, etc.).

Soil microorganisms including bacteria, fungi, actinomycetes, and symbiotic microbes such as rhizobia and mycorrhizae have an important role in process like nutrient acquisition (Sprent, 2001), nitrogen and carbon cycling
(Kowalchuk and Stephen, 2001; Hogberg et al., 2001), and soil aggregate formation (Rillig and Mummey, 2006). In addition, soil microbes can operate through two major mechanisms, popularly known as positive or negative feedback regulation mechanism in the process of interaction between plants and soils (Lü and Wu, 2018). In positive feedback, roles of soil microbes such as plant growth promoting rhizobacteria (PGPR), phosphate-solubilizing bacteria (PSB), and arbuscular mycorrhizal fungi (AMF) are well established in promoting plant growth, improving soil structure, and strengthening the resistance against biotic and abiotic stress (Bhattacharyya and Jha, 2012; Vimal et al., 2017). Zhang et al. (2015) further demonstrated that inoculation with an arbuscular mycorrhizal fungus Funneliformis mosseae on a replanted peach significantly improved soil structure. In negative feedback, soil microbes accelerate the off-site movement of nutrients, hinder plant growth, and reduce crop productivity. In this regard, large number of pathogens, parasites, and some plant-eating animals compete with plants for the carbon and other nutrients (Bever et al., 1997; Burdon et al., 2006). 
256

In this background, the present study was aimed to evaluate the inoculation response of replant soil microbes in plant growth and soil properties of peach $(P$. persica $\mathrm{L}$. Batsch) under controlled potted conditions.

\section{Materials and Methods}

\section{Experimentalset-up}

Seeds of peach provided by the Institute of Fruit and Tea, Hubei Academy of Agricultural Sciences, Wuhan, China, were germinated in autoclaved $\left(121^{\circ} \mathrm{C}, 0.11 \mathrm{MPa}, 2\right.$ h) sands with an average day/night temperature of $27 / 20^{\circ} \mathrm{C}$ and relative humidity of $80 \%$. After one month, 6-leaf-old peach seedlings with uniform size were transplanted into 2.5-L plastic pots supplied with $2.5 \mathrm{~kg}$ autoclaved $\left(121^{\circ} \mathrm{C}\right.$, $0.11 \mathrm{MPa}, 2 \mathrm{~h}$ ) soils. The soil was collected from the rhizosphere of 18-year-old $P$. persica cv. Yuhualu grafted on P. persica L. Batsch in the Boksugol $\left(30^{\circ} 25^{\prime} 15.1^{\prime \prime} \mathrm{N}\right.$ and $112^{\circ} 08^{\prime} 06.6^{\prime \prime} \mathrm{E}$ ) near the west campus of Yangtze University in Jingzhou, Hubei, China. The characteristics of the soil are $\mathrm{pH}$ 6.1, available $\mathrm{P} 12.5 \mathrm{mg} / \mathrm{kg}$, and organic carbon 11.2 $\mathrm{mg} / \mathrm{kg}$.

In addition, a portion of collected soil was passed through $2 \mathrm{~mm}$ sieve, soaked with sterile water (soil : water $=$ $1: 2, \mathrm{v} / \mathrm{v}$ ) for $24 \mathrm{~h}$, filtrated with nylon meshes of $\Phi 100-\mu \mathrm{m}$ and $\Phi 40-\mu \mathrm{m}$, and collected the filtrates named respectively, as $\mathrm{R}<100$ and $\mathrm{R}<40$ (Benzri et al., 2005).

\section{Experimental design}

The experiment was carried out in randomized blocked design with four treatments involving in different sizes of soil microbes: (i) autoclaved $\left(121{ }^{\circ} \mathrm{C}, 0.11 \mathrm{MPa}, 2 \mathrm{~h}\right)$ soils without any native microbes $\left(\mathrm{R}_{0}\right)$; (ii) autoclaved $\left(121^{\circ} \mathrm{C}\right.$, $0.11 \mathrm{MPa}, 2 \mathrm{~h}$ ) soils supplied with supernatants of $<40 \mu \mathrm{m}$ sized microbes $\left(\mathrm{R}_{<40}\right)$; (iii) autoclaved $\left(121^{\circ} \mathrm{C}, 0.11 \mathrm{MPa}, 2\right.$ h) soils supplied with supernatants of $<100 \mu \mathrm{m}$ sized microbes $\left(\mathrm{R}_{<100}\right)$; (iv) collected fresh soils containing all native microbes (R). Each treatment was replicated five times, with a total of 20 pots.

After five days of transplanting, peach seedlings with $\mathrm{R}_{<100}$ and $\mathrm{R}_{<40}$ were watered with $100 \mathrm{~mL}$ supernatants of $<$ $100 \mu \mathrm{m}$ and $<40 \mu \mathrm{m}$ microbes into pots at every five days, whilst a $100 \mathrm{~mL}$ distilled water/pot was supplied into the Rand $\mathrm{R}_{0}$-treated pots.

\section{Variable determinations}

All the peach seedlings were harvested after 90 days of growth and divided into shoots and roots, whose dry biomass was determined after drying thoroughly. The soil adhered on root surface was collected for onward analysis. Each root system from all treatments was scanned with an EPSON Flat-Scanner (V700, Seiko Epson Corp, Japan) and analyzed with the WinRHIZO 2007d (Regent Instruments Inc., Quebec, Canada) for root morphological traits including root total length, area, volume, and diameter.

Leaf chlorophyll concentration was measured as proposed by Knudson et al. (1977) using the extraction with $80 \%$ acetone solution.

Distribution of soil water-stable aggregates (WSAs) at the size of 2.00-4.00, 1.00-2.00, 0.50-1.00, and 0.25-0.50 $\mathrm{mm}$ was determined using the wet-sieving procedure (Kemper and Rosenau, 1986) with a soil aggregate analyzer (DM200-IV, Shanghai, China). Mean weight diameter (MWD) as an indictor of aggregate stability was calculated by the following formula (Kemper and Rosenau, 1986): MWD $=\sum_{i=1}^{n} X i W i$, where $X i$ is mean diameter of the $i$ sieve opening $(\mathrm{mm}), W i$ is proportion of the $i$ size fraction in the total sample mass, and $n$ is number of size fractions.

Soil organic carbon (SOC) was determined by spectrophotometry using dichromate wet oxidation method (Rowell, 1994). Determination of soil easily extractable glomalin-related soil protein (EE-GRSP) and difficulty extractable glomalin-related soil protein (DE-GRSP) was carried out following the protocol as outlined by Wu et al. (2015). Total glomalin-related soil protein (T-GRSP) is the sum of EE-GRSP and DE-GRSP.

Determination of soil polyphenol oxidase (PPO), peroxidase (POD), and catalase (CAT) activities was assayed following the procedure as suggested by Yan (1988).

\section{Statistical analysis}

The data (means $\pm \mathrm{SD}, n=5$ ) were statistically analyzed by one-way variance (ANOVA) in SAS v8.1 (SAS Institute Inc., Cary, USA), and the Duncan's Multiple Range Tests were used to compare the significance between treatments at the 0.05 level.

\section{Results and Discussion}

\section{Plant growth performance}

Plant growth performance is considered as a feedback indicator of rhizosphere properties (Ngullie et al., 2015). Compared with $\mathrm{R}_{0}$ treatment, $\mathrm{R}$ treatment registered a lower shoot weight, root weight, and total biomass weight (shoot plus root weight), leaf number, stem diameter, and plant height by $74 \%, 55 \%, 69 \%, 34 \%, 36 \%$, and $36 \%$, respectively (Table 1), suggesting that replant soil microbes had a negative feedback effect on plant growth parameters of peach. Such reduction in growth of peach plants is attributed to pathogens, parasites, and some plant-eating animals in the replant soil (Jonsson et al., 2001; Maherali and Klironomos, 2007; Van Der Heijden et al., 2008). While, compared with $\mathrm{R}_{0}$ treatment, $\mathrm{R}_{<100}$ treatment significantly reduced only plant height, shoot weight, and total weight by $11 \%, 30 \%$, and $25 \%$, respectively. The treatment $\mathrm{R}_{<40}$ likewise showed a higher magnitude of reduction in plants height and stem diameter by $20 \%$ and $16 \%$, respectively, indicating that replant soil microbes with the size of $<100 \mu \mathrm{m}$ were more inhibitory than $<40 \mu \mathrm{m}$ (Fig. 1). As a result, replant soil microbes mainly including pathogens in nature inhibited plant growth (Griffiths et al., 2000; Loreau, 2001; Garbeva et al., 2004). Earlier studies by Huang et al. (2018) showed that the application of higher concentration of soil water extract from Angelica sinensis rhizosphere, produced a distinct reduction in growth response, in terms of plant height, root length, and fresh weight. While, studies by Lau and Lennon (2011) revealed that complex soil microbial community could promote leaf number, above-ground biomass, and flower number in Brassica rapa. 
These studies are strongly suggestive of the rhizosphere microbial diversity depending upon the nature and properties of crop-specific rhizosphere biology.

\section{Root morphology}

Changes in root morphology affect the above-ground plant growth. An inhibitive effect of exogenously applied replant soil microbes (Fig. 1; Table 2) was observed over $R_{\text {o. }}$. Compared to $\mathrm{R}_{0}$ treatment, $\mathrm{R}$ treatment significantly reduced the total root length, projected area, and root volume by $22 \%, 17 \%$, and $35 \%$, respectively (Table 2 ). The treatment $\mathrm{R}_{<100}$ though, decreased these growth parameters to a lesser extent compared to R treatment by $20 \%, 15 \%$, and $25 \%$, respectively. However, $\mathrm{R}_{<40}$ treatment failed to induce any change in these root traits. It seems that replant soil microbes, especially with $\Phi<100 \mu \mathrm{m}$, but not $\Phi<40$ $\mu \mathrm{m}$, exhibited strong negative effects on root morphology of replanted peach. The soil microbe size of $\Phi<100 \mu \mathrm{m}$ directly hindered the root development possibly by producing toxic exudates to restrict the root growth (Caffaro et al., 2011; Sugiyama and Yazaki, 2012). On the other hand, $\mathrm{R}_{<40}$ treatment did not induce changes in growth root parameters such as root length, root area, root diameter, and root volume compared with $\mathrm{R}_{0}$ treatment, suggesting that $\Phi<40 \mu \mathrm{m}$ size soil microbes are less growth inhibitive on root growth. In previous studies, soil beneficial microbes, for example, AMF ( $\Phi 10 \mu \mathrm{m})$ recorded much higher magnitude of growth response than $\Phi<40 \mu \mathrm{m}$ (Allen, 2009). These microbes stimulated the root growth by reducing the relative abundance of toxic substances and producing auxins and polyamines, much to the added advantage in accelerating the root growth (Van Der Heijden et al., 2008; Zou et al., 2015; Lü and Wu, 2017).

Table 1. Effects of different sized soil microbes on plant growth performance of replanted peach (Prunuspersica) seedlings

\begin{tabular}{|c|c|c|c|c|c|c|}
\hline \multirow{2}{*}{ Treatments } & \multicolumn{3}{|c|}{ Dry weight (g/plant) } & \multirow{2}{*}{$\begin{array}{c}\text { Leaf number } \\
\text { (No/plant) }\end{array}$} & \multirow{2}{*}{$\begin{array}{l}\text { Plant height } \\
(\mathrm{cm})\end{array}$} & \multirow{2}{*}{$\begin{array}{l}\text { Stem diameter } \\
(\mathrm{mm})\end{array}$} \\
\hline & Shoot & Root & Total & & & \\
\hline $\mathrm{R}_{0}$ & $2.20 \pm 0.27 \mathrm{a}$ & $0.98 \pm 0.27 \mathrm{a}$ & $3.18 \pm 0.48 \mathrm{a}$ & $32.4 \pm 5.9 \mathrm{a}$ & $44.2 \pm 4.2 \mathrm{a}$ & $3.60 \pm 0.60 \mathrm{a}$ \\
\hline $\mathrm{R}_{<40}$ & $1.90 \pm 0.18 \mathrm{a}$ & $0.94 \pm 0.14 \mathrm{a}$ & $2.84 \pm 0.20 \mathrm{a}$ & $27.6 \pm 5.0 \mathrm{a}$ & $35.5 \pm 4.4 \mathrm{~b}$ & $3.02 \pm 0.35 b$ \\
\hline $\mathrm{R}<100$ & $1.54 \pm 0.30 \mathrm{~b}$ & $0.84 \pm 0.33 \mathrm{a}$ & $2.38 \pm 0.47 \mathrm{~b}$ & $27.2 \pm 3.3 \mathrm{ab}$ & $39.2 \pm 1.9 \mathrm{~b}$ & $3.54 \pm 0.30 \mathrm{a}$ \\
\hline $\mathrm{R}$ & $0.57 \pm 0.06 c$ & $0.44 \pm 0.17 b$ & $1.00 \pm 0.22 c$ & $21.4 \pm 2.3 b$ & $28.4 \pm 1.6 c$ & $2.30 \pm 0.14 \mathrm{c}$ \\
\hline
\end{tabular}

Note: Data (means \pm SD, $n=5$ ) followed by different letters among treatments indicate significant differences at $5 \%$ level. Abbreviations: $\mathrm{R}_{0}=$ autoclaved replanted soil without any microbes; $R_{<40}=$ autoclaved replanted soil treated by $\Phi<40 \mu \mathrm{m}$ soil microbes; $\mathrm{R}<100=$ autoclaved replanted soil treated by $\Phi<100 \mu \mathrm{m}$ soil microbes; $\mathrm{R}=$ non-autoclaved replanted soil.

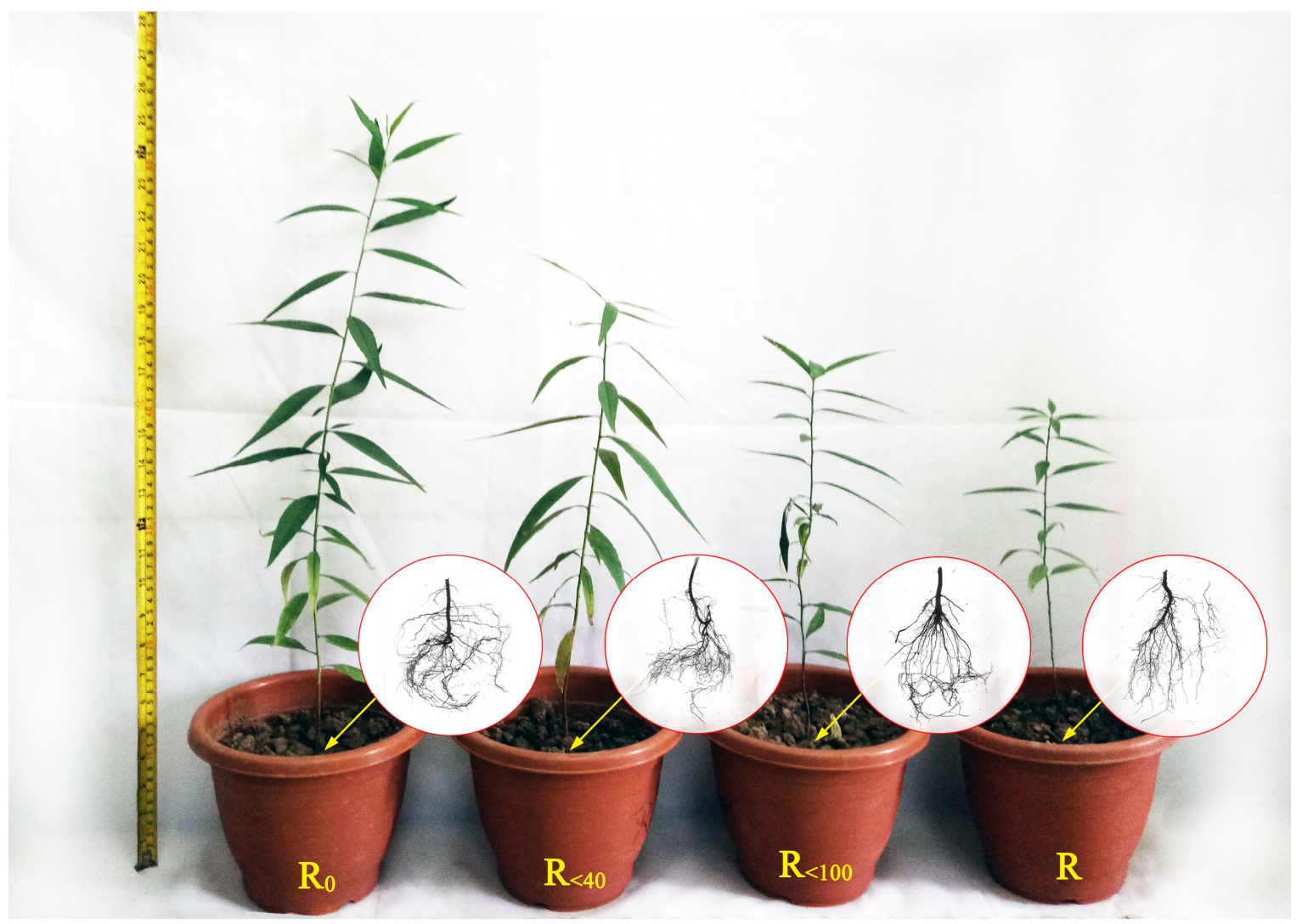

Fig. 1. Effects of replanted soil microbes on plant growth and root architecture system of replanted peach (Prunus persica) seedlings 
Table 2. Effects of different sized soil microbes on root morphological traits of replanted peach (Prunus persica) seedlings

\begin{tabular}{|c|c|c|c|c|c|}
\hline Treatments & $\begin{array}{c}\text { Total length } \\
(\mathrm{cm})\end{array}$ & $\begin{array}{l}\text { Projected area } \\
\qquad\left(\mathrm{cm}^{2}\right)\end{array}$ & $\begin{array}{c}\text { Surface area } \\
\left(\mathrm{cm}^{2}\right)\end{array}$ & $\begin{array}{l}\text { Average diameter } \\
(\mathrm{mm})\end{array}$ & $\begin{array}{c}\text { Volume } \\
\left(\mathrm{cm}^{3}\right)\end{array}$ \\
\hline $\mathrm{R}_{0}$ & $222.91 \pm 13.35 a$ & $13.17 \pm 0.49 a$ & $16.94 \pm 1.07 \mathrm{ab}$ & $0.46 \pm 0.02 \mathrm{ab}$ & $1.07 \pm 0.16 \mathrm{a}$ \\
\hline $\mathrm{R}_{<40}$ & $217.35 \pm 10.35 a$ & $12.38 \pm 0.76 \mathrm{ab}$ & $17.58 \pm 0.54 \mathrm{a}$ & $0.48 \pm 0.04 \mathrm{a}$ & $0.99 \pm 0.24 \mathrm{ab}$ \\
\hline $\mathrm{R}<100$ & $178.61 \pm 19.73 b$ & $11.15 \pm 1.23 b$ & $16.02 \pm 0.42 b$ & $0.41 \pm 0.03 b$ & $0.80 \pm 0.17 \mathrm{c}$ \\
\hline $\mathrm{R}$ & $173.70 \pm 35.46 b$ & $10.88 \pm 1.67 b$ & $15.90 \pm 1.49 b$ & $0.33 \pm 0.03 c$ & $0.70 \pm 0.15 c$ \\
\hline
\end{tabular}

Note: Data (means \pm SD, $n=5$ ) followed by different letters among treatments indicate significant differences at $5 \%$ level. Abbreviations: $\mathrm{R}_{0}=$ autoclaved replanted soil without any microbes; $\mathrm{R}_{<40}=$ autoclaved replanted soil treated by $\Phi<40 \mu \mathrm{m}$ soil microbes; $\mathrm{R}_{<100}=$ autoclaved replanted soil treated by $\Phi<100 \mu \mathrm{m}$ soil microbes; $\mathrm{R}=$ non-autoclaved replanted soil.

\section{Chlorophyll concentrations}

Response on plant biomass is by and large regulated through changes in chlorophyll concentration. Our results displayed that compared to $R_{0}$ treatment, both $R_{<40}$ and $\mathrm{R}_{<100}$ did not produced no significance difference in concentration of leaf chlorophyll $a$, chlorophyll $b$, and carotenoid concentrations (Fig. 2). While, $\mathrm{R}$ treatment drastically reduced the leaf chlorophyll $a$, chlorophyll $b$, and carotenoid concentration.

These results are in agreement with Huang et al. (2018) in Angelica membranaceu and Cannabis sativa. Lau and Lennon (2011) on the other hand, reported that complex microbial community significantly improved chlorophyll concentrations of Brassica rapa through increase photosynthetic efficiency, compared to simple microbial community. Our observations suggested that all soil microbes derived from fresh replant soil produce a negative feedback regulation on chlorophyll synthesis of peach plants, possibly related to reduce availability of nutrients like $\mathrm{Mg}$, N, and Fe.

\section{Glomalin-related soil protein (GRSP), WSAs and SOC}

GRSP produced by AMF is closely related to soil organic matter and plays an important role in the formation of soil aggregates, soil carbon budget and resistance to stresses in plants (Barea et al., 2013). GRSP is considered to be the focal point of structural stability of soil (Wu et al., 2016). The concentration of soil EE-GRSP, DE-GRSP and TGRSP were observed to increase by $9 \%, 8 \%$, and $8 \%$ with $\mathrm{R}_{<40}$ treatment, by $91 \%, 32 \%$, and $47 \%$ with $\mathrm{R}_{<100}$ treatment, and by $55 \%, 5 \%$, and $19 \%$ with $\mathrm{R}$ treatment, compared to $\mathrm{R}_{0}$ treatment (Fig. 3). These observations further suggested that peach rhizosphere soils with $\mathrm{R}_{<100}$ treatment produced relatively higher soil GRSP levels, due to stimulation in PGPR via spore germination and mycelium elongation of
AMF, leading to better production efficiency of GRSP (Driver et al., 2005; Bedini et al., 2009; Wu et al., 2016), however, in agreement with replanted peach inoculated with Funneliformis mosseae (Zhang et al., 2015). Soil microorganisms such as nematodes and collembolan are reported to have a negative effect on GRSP production by AM hyphae to reduce further proliferation and spread of hyphae network (Bedini et al., 2009).

Changes in soil structure are directly guided by SOC. Soil WSAs are closely associated with water infiltration rate, tilth and aeration in soils (Kemper and Rosenau, 1986). WSAs are an important index of soil structural stability, which is regulated by a variety of aggregate stabilizing agents like roots, SOC, soil enzymes, and soil microbial community (Rillig, 2004; Rillig and Mummey, 2006; Wu et al., 2012; Peng et al., 2013). SOC plays an adhesion role in the initial formation of soil aggregates (Bronick and Lal, 2005). Soil microbes can potentially affect soil WSAs at different levels through hyphae network and their secreted organic polymers (Rillig and Mummey, 2006; Griffiths et al., 2008; Wang et al., 2014). In our study, compared to $\mathrm{R}_{0}$ treatment, $\mathrm{R}$ treatment significantly reduced WSA $2.00-4.00 \mathrm{~mm}$ by $65 \%$ and increased WSA $\mathrm{W}_{0.50-1.00 \mathrm{~mm}}$ and $\mathrm{WSA}_{0.25-0.50 \mathrm{~mm}}$ by $38 \%$ and $54 \%$ (Table 3). $\mathrm{R}_{<100}$ treatment significantly reduced WSA $2.00-4.00 \mathrm{~mm}$ and $\mathrm{WSA}_{0.50-1.00 \mathrm{~mm}}$ by $48 \%$ and $31 \%$, and increased WSA $0.25-0.50 \mathrm{~mm}$ by $62 \%$, over $\mathrm{R}_{0}$ treatment. Soil MWD and SOC respectively, declined by $41 \%$ and $19 \%$

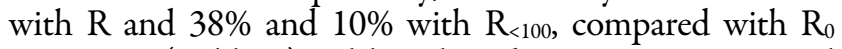
treatment (Table 3). Although a distinct increase in soil GRSP level was observed in inoculated seedlings, a lower soil WSA distribution, SOC, and MWD in inoculated seedlings showed that microbial release of GRSP is not the deciding factor in soil structural improvement, because root surface, root exudates, SOC, and soil enzymes all modulate soil structure formation (Wu et al., 2015).

Table 3. Effects of different sized soil microbes on distribution of water-stable aggregate (WSA), mean weight diameter (MWD), and soil organic carbon (SOC) concentrations of replanted peach (Prunus persica) seedlings

\begin{tabular}{|c|c|c|c|c|c|c|}
\hline \multirow{2}{*}{ Treatments } & \multicolumn{4}{|c|}{ Distribution of WSAs (\%) } & \multirow{2}{*}{ MWD (mm) } & \multirow{2}{*}{$\mathrm{SOC}(\mathrm{mg} / \mathrm{g})$} \\
\hline & $2.00-4.00 \mathrm{~mm}$ & $1.00-2.00 \mathrm{~mm}$ & $0.50-1.00 \mathrm{~mm}$ & $0.25-0.50 \mathrm{~mm}$ & & \\
\hline $\mathrm{R}_{0}$ & $0.31 \pm 0.10 \mathrm{a}$ & $0.14 \pm 0.06 \mathrm{a}$ & $0.13 \pm 0.03 b$ & $0.13 \pm 0.05 b$ & $1.28 \pm 0.22 \mathrm{a}$ & $11.97 \pm 0.30 \mathrm{a}$ \\
\hline $\mathrm{R}_{<40}$ & $0.24 \pm 0.09 \mathrm{ab}$ & $0.15 \pm 0.05 \mathrm{a}$ & $0.15 \pm 0.01 \mathrm{ab}$ & $0.20 \pm 0.08 \mathrm{a}$ & $1.15 \pm 0.22 \mathrm{a}$ & $11.17 \pm 0.67 b$ \\
\hline $\mathrm{R}_{<100}$ & $0.16 \pm 0.10 b c$ & $0.12 \pm 0.08 \mathrm{a}$ & $0.09 \pm 0.03 \mathrm{c}$ & $0.21 \pm 0.08 \mathrm{a}$ & $0.80 \pm 0.25 b$ & $10.80 \pm 0.21 b$ \\
\hline $\mathrm{R}$ & $0.11 \pm 0.04 \mathrm{c}$ & $0.14 \pm 0.04 \mathrm{a}$ & $0.18 \pm 0.02 \mathrm{a}$ & $0.20 \pm 0.03 \mathrm{a}$ & $0.75 \pm 0.13 b$ & $9.73 \pm 0.54 \mathrm{c}$ \\
\hline
\end{tabular}

Note: Data (means \pm SD, $n=5$ ) followed by different letters among treatments indicate significant differences at $5 \%$ level. Abbreviations: $\mathrm{R}_{0}=$ autoclaved replanted soil without any microbes; $R_{<40}=$ autoclaved replanted soil treated by $\Phi<40 \mu \mathrm{m}$ soil microbes; $R_{<100}=$ autoclaved replanted soil treated by $\Phi<100 \mu \mathrm{m}$ soil microbes; $\mathrm{R}=$ non-autoclaved replanted soil. 


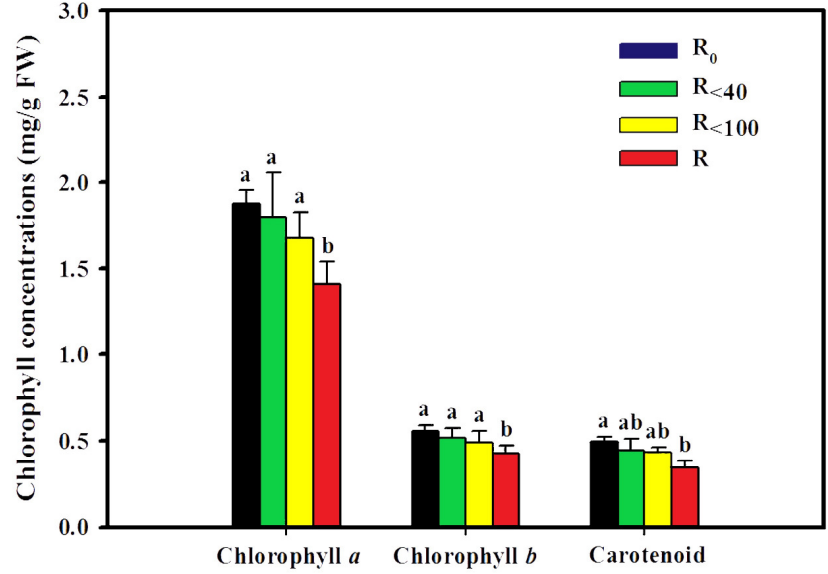

Fig. 2. Effects of different sized replanted soil microbes on chlorophyll $a$, chlorophyll $b$ and carotenoid concentrations of peach (Prunus persica) seedlings. Data (means \pm SD, $n=5$ ) followed by different letters among treatments indicate significant differences at the $5 \%$ level

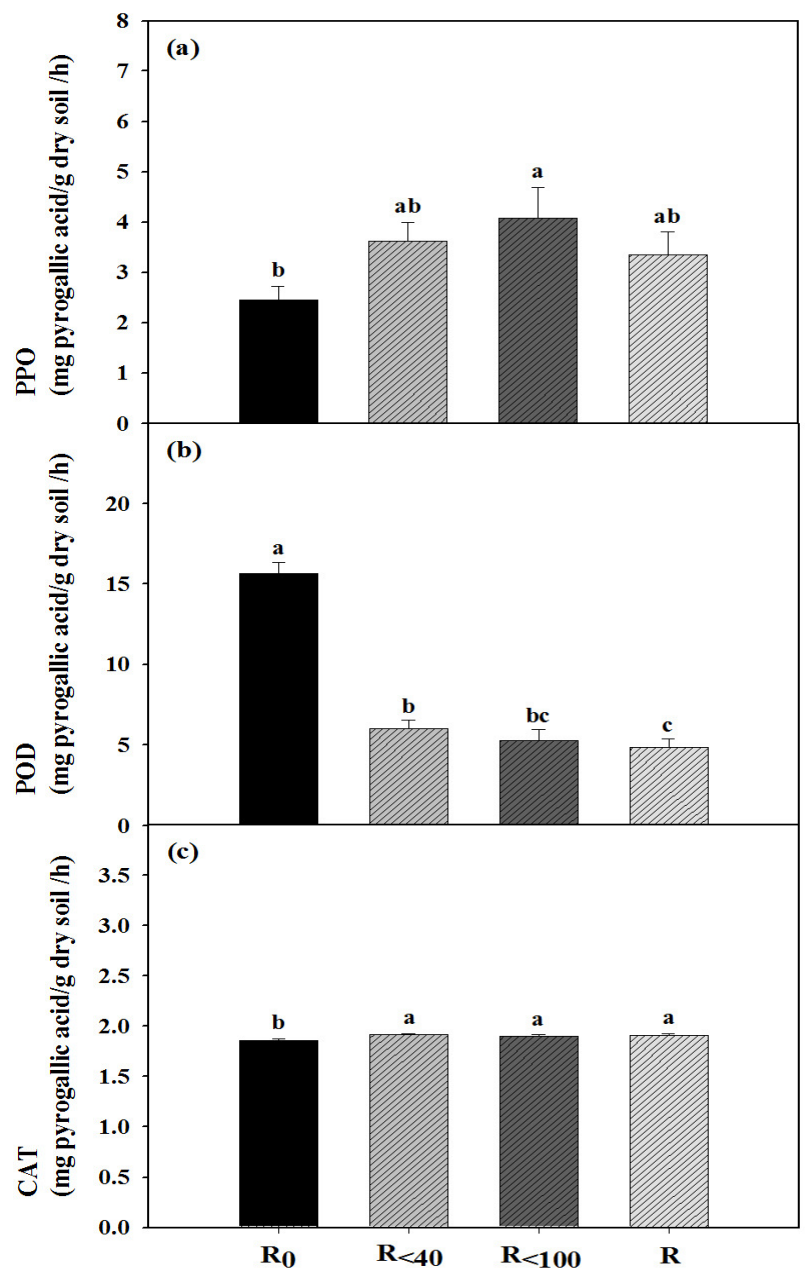

Fig. 4. Effects of different sized replanted soil microbes on activities of polyphenol oxidase (PPO) (a), peroxidase (POD) (b) and catalase (CAT) (c) of peach (Prunus persica) seedlings. Data (means $\pm \mathrm{SD}, n=5$ ) followed by different letters among treatments indicate significant differences at the $5 \%$ level

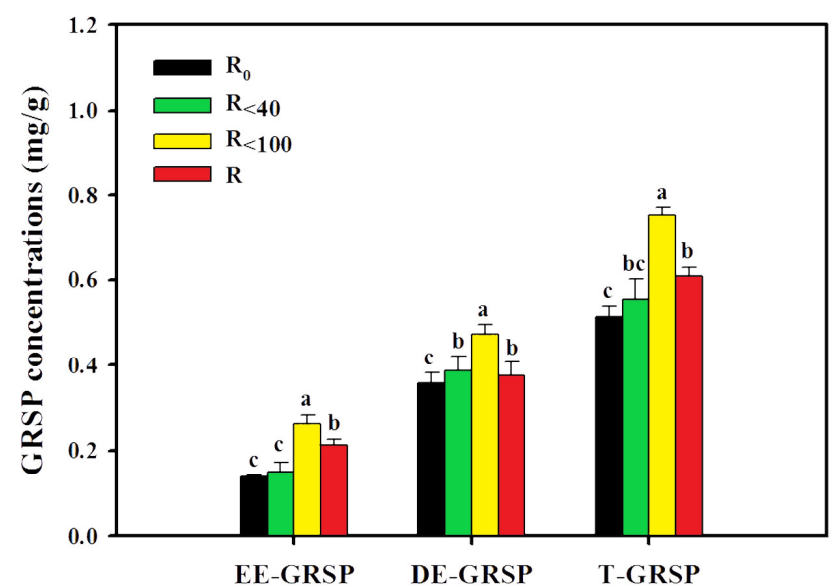

Fig. 3. Effects of different sized replanted soil microbes on easily extractable glomalin-related soil protein (EE-GRSP), difficulty extractable glomalin-related soil protein (DE-GRSP), and total glomalin-related soil protein (T-GRSP) concentrations of peach (Prunus persica) seedlings. Data (means $\pm \mathrm{SD}, n=5$ ) followed by different letters among treatments indicate significant differences at the $5 \%$ level

\section{Soil antioxidant enzyme activities}

Soil enzymes play an important role in energy transformation and nutrient cycling in soil-based ecosystems (Bowles et al., 2014). Soil enzymatic activities are closely related to soil microbial flora, quantity and biodiversity, heavily promoting soil metabolic processes (Taylor et al., 2002; Finkenbein et al., 2013). Soil PPO can oxidize the aromatic compounds in soil and generate organic matters and pigments, thus completing the soil aromatic compounds cycle (Toscano et al., 2003). PPO on the other hand, holds an equally important role in transforming heterocyclic compounds (i.e., PAHs) in soils, coupled with positive effects of GRSP on the availability of PAHs (Sun et al., 2012; Gao et al., 2017). Hence, soil microbes, especially with the size of $\Phi<100 \mu \mathrm{m}$ significantly increased soil PPO activities, in association with an increase of GRSP (Fig. 4a). Soil POD mainly comes from soil microorganisms, which plays an important role in the formation of humus (Wang et al., 2010). Our results indicated that three soil microbial treatments significantly reduced soil POD activities (Fig. 4b). This is in agreement with Zhang et al. (2015) earlier reported similar response on soil POD and soil PPO activities of replanted peach. Toxic substances released by roots or soil microbes required POD to perform degradation, thereby, resulted a decrease in soil POD activity (Kong, 2007; Wang et al., 2010). Soil CAT is derived from the decomposition of plants and exerts effects on removing the toxic effect of soil hydrogen peroxide (Liu et al., 2008). CAT is closely related to soil microbial abundance and plant roots biomass, which breaks down hydrogen peroxide in the soil to reduce its toxic effects on plants (Liu et al., 2008). Such a considerable increase in soil CAT activities by soil microbial treatments (Fig. 4c) as seen through our observations would partly alleviate toxic effects of hydrogen peroxide on plants.

Furthermore, $\mathrm{R}_{<100}$ treatment represented strong inhibitory effects on biomass production, root development 
260

and soil physicochemical traits, relative to $\mathrm{R}_{<40}$ treatment. It might be due to the fact that $\mathrm{R}_{<100}$ treatment contained a mass of pathogenic organisms with the size of $40-100 \mu \mathrm{m}$, such as Rbizoctonia solani (Qin et al., 2014), Ralstonia solanacerum (Chen et al., 2011), Fusarium wilt (Akköprü and Demir, 2005), Pythium, Phytophthora (Spies et al., 2011), etc. Therefore, such pathogens of $R_{<100}$ treatment might trigger the inhibitive effect.

\section{Conclusions}

Replant soil microbes inhibited plant growth performance, root growth, soil aggregation, SOC, and soil PPO activities, especially the soil microbes locked within the size of $\Phi<100 \mu \mathrm{m}$ showed the heaviest negative response. With peach as continuous rotation, soil microbes with $\Phi<$ $100 \mu \mathrm{m}$ need to be eliminated to mitigate the issues related to soil replant disease. However, it remains to be seen, after how many rotations (cropping seasons) such replant issue becomes more distinctive in a given crop-soil-climate setup, alongside the associated biochemistry involved.

\section{Acknowledgements}

This study was supported by the Plan in Scientific and Technological Innovation Team of Outstanding Young, Hubei Provincial Department of Education (T201604).

\section{References}

Akköprü A, Demir S (2005). Biological control of Fusarium wilt in tomato caused by Fusarium oxysporum f. sp. lycopersici by AMF Glomus intraradices and some rhizobacteria. Journal of Phytopathology 153:544550.

Allen MF (2009). Water relations in the mycorrhizosphere. In: Lüttge U, Beyschlag W, Büdel B, Francis D (Eds). Progress in botany. Springer, VerlagBerlin Heidelbergpp 257-276.

Barea, JM, Pozo MJ, López-Ráez JM, Aroca R, Ruiz-Lozano JM, Ferrol N, Azcón R, Azcon-Aguilar C (2013). Arbuscular mycorrhizas and their significance in promoting soil-plant system sustainability against environmental stresses.In: González MBR, Gonzalez-López J (Eds). Beneficial Plant-microbial Interactions: Ecology and Applications. Boca Raton, FL: CRC Press pp 353-387.

Bedini S, Pellegrino E, Avio L, Pellegrini S, Bazzoffi P, Argese E, Giovannetti $M(2009)$. Changes in soil aggregation and glomalin-related soil protein content as affected by the arbuscular mycorrhizal fungal species Glomus mosseae and Glomus intraradices. Soil Biology and Biochemistry 41:1491-1496.

BentE, Loffredo A, YangJI, McKenry MV, Becker JO, Borneman J (2009). Investigations into peach seedlings stunting causing by a replant soil. FEMS Microbiology Ecology 68:192-200.

Benzri E, Pintti S, Verger S, Pagés L, Vercambre G, Poessel JL, Michelot P (2005). Replant disease: Bacterial community structure and diversity in peach rhizosphere as determined by metabolic and genetic fingerprinting. Soil Biology and Biochemistry 37:1738-1746.
Bever JD, Westover KM, Antonovics J (1997). Incorporating the soil community into plant population dynamics: the utility of the feedback approach.Journal of Ecology 85:561-573.

Bhattacharyya PN, Jha DK (2012). Plant growth-promoting rhizobacteria (PGPR): emergence in agriculture. World Journal of Microbiology and Biotechnology 28:1327-1350.

Bowles TM, Acosta-Martínez V, Calderón F, Jackson LE (2014). Soil enzyme activities, microbial communities, and carbon and nitrogen availability in organic agroecosystems across an intensively-managed agricultural landscape. Soil Biology and Biochemistry 68:252-262.

Bronick CJ, Lal R (2005). Soil structure and management: A review. Geoderma 124:3-22.

Burdon JJ, Thrall PH, Ericson AL (2006). The current and future dynamics of disease in plant communities. Annual Review of Physiology 44: 1939.

Caffaro MM, VivancoJM, Boem FHG, Rubio G (2011). The effect of root exudates on root architecture in Arabidopsis thaliana. Plant Growth Regulation 64:241-249.

Chen GZ, Ye WY, Chen QP, Wu CZ, Wu CL, Wei CH, Wei HW (2011). Peanut bacterial wilt and adjustment measures for continuous cropping obstacle. Anhui Agriculture 11:191-192 (in Chinese with Engish abstract).

DriverJD, Holben WE, RilligMC (2005). Characterization of glomalin as a hyphal wall component of arbuscular mycorrhizal fungi. Soil Biology and Biochemistry 37:101-105.

Finkenbein P, Kretschmer K, Kuka K, Klotz S, Heilmeier H (2013). Soil enzyme activities as bioindicators for substrate quality in revegetation of a subtropical coal miningdump. Soil biology and Biochemistry 56:87-89.

Gao Y, Zhou Z, Ling W, Hu X, Chen S (2017). Glomalin-related soil protein enhances the availability of polycyclic aromatic hydrocarbons in soil. Soil Biology and Biochemistry 107:129-132.

Garbeva P, Veen JAV, ElsasJDV (2004). Microbial diversity in soil: selection of microbial populations by plant and soil type and implications for disease suppressiveness. Annual Review of Phytopathology 42:243-270.

Griffiths BS, Hallett PD, Kuan HL, Gregory AS, Watts CW, Whitmore AP (2008). Functional resilience of soil microbial communities depends on both soil structure and microbial community composition. Biology and Fertility ofSoils 44:745-754.

Griffiths BS, Ritz K, Bardgett RD, Cook R, Christensen S, Ekelund F, Sorensen SJ, Baath E, Bloem J, de Ruiter PC, Dolfing J, Nicolardot B (2000). Ecosystem response of pasture soil communities to fumigationinduced microbial diversity reductions: an examination of the biodiversity-ecosystem function relationship. Oikos 90:279-294.

Hogberg P, Nordgren A, Buchmann N, Taylor AFS, Ekblad A, Hogberg MN Nyberg G, Ottosson-Löfvenius M, Read DJ (2001). Large-scale forest girdling shows that current photosynthesis drives soil respiration. Nature 411:789-792.

Huang WJ, Sun XC, WangN, WangEH, GaoJ, Sun JX, Tian X, TangZS (2018). Allelopathy of rhizosphere soil aqueous extract from angelica sinensis on seedling growth of $A$. membranaceu and industrial hemp (Cannabis sativa L.). Plant Fiber Sciences in China 40:63-69 (in Chinese with English abstract). 
Jonsson LM, Nilsson MC, Wardle DA, Zackrisson O (2001). Context dependent effects of ectomycorrhizal species richness on tree seedling productivity. Oikos 93:353-364.

Kemper WD, Rosenau R (1986). Aggregate stability and size distribution. In: Klute A (Ed). Methods of Soil Analysis, Part 1. Physical and Mineralogical Methods. Agronomy Monograph. American Society of Agronomy and Soil Science Society of America, USA pp $425-442$.

Knudson LL, Tibbitts TW, Edwards GE (1977). Measurement of ozone injury by determination of leaf chlorophyll concentration. Plant Physiology 60:606-608.

Kong LG (2007). Studies on soil rhizosphere effect of continuous cropping poplar plantation. $\mathrm{PhD}$ Thesis, Shandong Agricultural University, Taỉan (in Chinese with English abstract).

Kowalchuk GA, Stephen JR (2001). Ammonia-oxidizing bacteria: a model for molecular microbial ecology. Annual Review of Microbiology 55:485-529.

Lau JA, Lennon JT (2011). Evolutionary ecology of plant-microbe interactions: soil microbial structure alters selection on plant traits. New Phytologist 192:215-224.

Liu J, Xie J, Chu Y, Sun C, Chen C, Wang Q (2008). Combined effect of cypermethrin and copper on catalase activity in soil. Journal of Soils and Sediments 8:327-332.

Loreau M (2001). Microbial diversity, producer-decomposer interactions and ecosystem processes: a theoretical model. Proceedings of the Royal Society of London B: Biological Sciences 268:303-309.

Lü LH, Wu QS (2017). Mycorrhizas promote plant growth, root morphology and chlorophyll production in white clover. Biotechnology 16:3439.

Lü LH, Wu QS (2018). Mitigation of replant disease by mycorrhization in horticultural plants: A review. Folia Horticulturae 30:269-282.

Maherali H, Klironomos JN (2007). Influence of phylogeny on fungal community assembly and ecosystem functioning. Science 316:17461748.

Ngullie E, Singh AK, Sema A and Srivastava AK (2015). Citrus growth and rhizosphere properties. Communications in Soil Science and Plant Analysis 46:1540-1550.

Qin HB, Zhang ZB, He CX (2014). Study of tolerance effects on blight of cucumber seedlings induced by arbuscular mycorrhizal fungi. Acta Agriculturas Boreali-Sinica 29:98-102 (in Chinese with English abstract).

Rillig MC, Mummey DL (2006). Mycorrhizas and soil structure. New Phytologist 171:41-53.

Rowell DL (1994). Soil science: methods and applications. Longman Group Limited, Longman Scientific and Technical, Harlow.

SprentJI (2001). Nodulation in legumes. Royal Botany, Gardens, Kew, UK.

Spies CFJ, Mazzola M, McLeod A (2011). Characterisation and detection of Pythium and Phytophthora species associated with grapevines in South Africa. European Journal of Plant Pathology 131(1):103-119.

Sugiyama A, Yazaki K (2012). Root exudates of legume plants and their involvement in interactions with soil microbes. In: Vivanco J, Baluška F (Eds). Secretions and exudates in biological systems. Signaling and communication in plants, vol 12. Springer, Berlin, Heidelbergpp 27-48.
Sun B, Gao Y, Liu J, Sun Y (2012). The impact of different root exudate components on phenanthrene availability in soil. Soil Science Society of America Journal 76:2041-2050.

Sun XT, Li L, Long GQ, Zhang GH, Meng ZH, Yang SC, Chen WJ (2015). The progress and prospect on consecutive monoculture problems of Panax notoginseng. Chinese Journal of Ecology 34: 885-893 (in Chinese with English abstract).

TaylorJP, Wilson B, Mills MS, Burns RG (2002). Comparison of microbial numbers and enzymatic activities in surface soils and subsoils using various techniques. Soil Biology and Biochemistry 34:387-401.

Tewoldemedhin YT, Mazzola M, Labuschagne I, McLeod A (2011). A multi-phasic approach reveals that apple replant disease is caused by multiple biological agents, with some agents acting synergistically. Soil Biology and Biochemistry 43:1917-1927.

Toscano G, Colarieti ML, Jr GG (2003). Oxidative polymerisation of phenols by a phenol oxidase from green olives. Enzyme \& Microbial Technology 33:47-54.

Van Der Heijden MG, Bardgett RD, Van Straalen NM (2008). The unseen majority: soil microbes as drivers of plant diversity and productivity in terrestrial ecosystems. Ecology Letters 11:296-310.

Vimal SR, Singh JS, Arora NK, Singh S (2017). Soil-plant-microbe interactions in stressed agriculture management: A review. Pedosphere 27:177-192.

Wang S, Srivastava AK, Wu QS, Fokom R (2014). The effect of mycorrhizal inoculation on the rhizosphere properties of trifoliate orange (Poncirus trifoliata L. Raf.). Scientia Horticulturae 17:137-42.

Wang ZG, Xu WH, Guo TW (2010). Effects of Chinese chives' continuous cropping on microbial quantity and enzymes activities in the soil of big cote. Chinese Journal of Soil Science 41:1048-1052 (in Chinese with English abstract).

Wu QS, Li Y, Zou YN, He XH (2015). Arbuscular mycorrhiza mediates glomalin-related soil protein production and soil enzyme activities in the rhizosphere of trifoliate orange grown under different $\mathrm{P}$ levels. Mycorrhiza25:121-130.

Wu QS, Shuang W, Srivastava AK (2016). Mycorrhizal hyphal disruption induces changes in plant growth, glomalin-related soil protein and soil aggregation of trifoliate orange in a core system. Soil and Tillage Research 160:82-91.

Yan CR(1988). Research methods of soil fertility. Agricultural Press, Beijing pp 133-138.

Zhang ZZ, Srivastava AK, Wu QS, Li GH (2015). Growth performance and rhizospheric traits of peach (Prunus persica) in response to mycorrhization on replant versus non-replant soil. Indian Journal of Agricultural Sciences 85:125-130.

Zou YN, Srivastava AK, NiQD, Wu QS (2015).Disruption of mycorrhizal extraradical mycelium and changes in leaf water status and soil aggregate stability in rootbox-grown trifoliate orange. Frontiers in Microbiology 6:203. 